\title{
Do bioturbation and consumption affect coastal Arctic marine soft-bottom communities?
}

\author{
Sina Petrowski • Markus Molis • Katrin Schachtl • \\ Christian Buschbaum
}

Received: 4 September 2014/Revised: 15 January 2015/ Accepted: 26 January 2015 / Published online: 7 February 2015

(C) Springer-Verlag Berlin Heidelberg 2015

\begin{abstract}
Biotic factors such as bioturbation and predation affect abundance and species composition of marine soft-bottom communities from tropical to temperate regions, but their impact has been rarely investigated in Arctic coastal systems. By conducting a factorial manipulative field experiment, we excluded the bioturbating lugworm Arenicola marina and predacious consumers from a sedimentary nearshore area in Kongsfjorden (Spitsbergen) for 70 days to explore their role in structuring the benthic community. The removal of $A$. marina caused an increase in average species number by $25 \%$, a doubling increase in the average number of individuals and an increase in dry mass of benthic organisms by, on average, $73 \%$ in comparison with untreated areas. Additionally, community composition was significantly modified by lugworm exclusion resulting in higher average densities of the cumacean Lamprops fuscatus (4.2-fold), the polychaete worms Euchone analis (3.7-fold) and Pygospio cf. elegans (1.5-fold), the bivalve
\end{abstract}

This article belongs to the special issue on the "Kongsfjorden ecosystem-new views after more than a decade of research", coordinated by Christian Wiencke and Haakon Hop.

S. Petrowski - M. Molis

Alfred Wegener Institute, Helmholtz Centre for Polar and Marine Research, Am Handelshafen 12, 27570 Bremerhaven, Germany

K. Schachtl · C. Buschbaum ( $\square)$

Alfred Wegener Institute, Helmholtz Centre for Polar and Marine Research, Wadden Sea Station Sylt, Hafenstrasse 43, 25992 List/Sylt, Germany

e-mail: christian.buschbaum@awi.de

K. Schachtl

Ludwig-Maximilians-Universität München, Aquatische Ökologie, Großhaderner Straße 2, 82152 Martinsried-Planegg, Germany
Crenella decussata (2.8-fold) and the amphipod Crassicorophium crassicorne (1.2-fold), which primarily contribute to the observed differences. Consumer exclusion, by contrast, showed no effects on the response variables. This result was independent from bioturbation due to missing interaction between both biotic factors. We conclude that present levels of bioturbation may considerably affect Arctic coastal soft-bottom communities. In contrast, predation by macro-epibenthic consumers currently seems to be of minor importance. This might change in a predicted warmer Arctic with assumed higher predator abundances and a northward expansion of boreal consumers.

Keywords Bioturbation - Predation - Soft-bottom benthos $\cdot$ Arctic shallow water . Field experiment

\section{Introduction}

The identification of general mechanisms controlling structure and dynamics of coastal species assemblages is a major goal of marine community ecology. Besides competition, especially predation and bioturbation are considered to be important biotic factors determining the species composition of marine soft-bottom communities from temperate to tropical systems (e.g. Wilson 1991; Woodin 1999; Berkenbusch et al. 2000; Cadée 2001; Reise 2002; Flach 2003; Meysman et al. 2006; Volkenborn and Reise 2007; Pillay and Branch 2011; Passarelli et al. 2014). While the consumption by predators affects directly prey population dynamics, bioturbation by burrowing organisms such as polychaetes, holothurians and crustaceans can cause substantial sediment disturbances and, thus, sediment-mediated indirect species interactions (Wilson 1991; Reise 2002; González-Ortiz et al. 2014). Sediment- 
reworking polychaetes such as the lugworm Arenicola marina or callianassid shrimps, for example, preempt the habitat by high rates of sediment turnover with inhibitive but also facilitative effects for other organisms (Riisgard and Banta 1998; Reise 2002; Volkenborn and Reise 2006).

To explore the effects of species interactions on community structure and population dynamics in soft-bottom environments, descriptive investigations may reveal general patterns (Rabaut et al. 2007), but they are not suitable for identifying the underlying processes (Volkenborn and Reise 2006). Thus, manipulative experiments are crucial to specify the linkage from species interactions to community patterns. One appropriate approach is the intentional removal or addition of key organisms in field experiments (Paine 1980; Wilson 1991; Reise 2002). This approach has been, for instance, successfully used in eliciting predation and bioturbation as important drivers of species diversity and dynamics in marine soft-sediment communities of lower latitudes (e.g. Reise 1985; Flach 1992; Passarelli et al. 2014 and references therein). However, as far as we know such manipulative field experiments have rarely been performed in polar marine environments (but see Konar 2007, 2013; Beuchel and Gulliksen 2008), with no information available on the effects of consumption and bioturbation on Arctic soft-bottom communities. Thus, most information on species occurrence, interactions and population dynamics in benthic Arctic coastal systems relies on observational studies (Hop et al. 2002).

The objective of this high-latitude study was to investigate the effects of consumption and bioturbation on an Arctic marine soft-sediment species assemblage by conducting a combined bioturbator and predator exclusion field experiment. Our study was performed in Kongsfjorden (West Spitsbergen), an intensively studied area for which the physical conditions and biota are well documented (Hop et al. 2002; Svendsen et al. 2002; Wlodarska-Kowalczuk and Pearson 2004; Kaczmarek et al. 2005; Kedra et al. 2010; Voronkov et al. 2013 and references therein). For the intertidal and shallow subtidal softbottom area in Kongsfjorden, it is generally assumed that occurrence and dynamics of species assemblages are predominantly triggered by abiotic factors such as ice scouring, meltwater discharge and a high sedimentation rate provoking the colonization of these areas with opportunistic, small macrofauna organisms (Ambrose and Leinaas 1988; Gutt 2001; Bick and Arlt 2005; Wlodarska-Kowalczuk et al. 2005; Laudien et al. 2007; Veit-Köhler et al. 2008). These species are well adapted to natural disturbances, and their high reproduction rates enable them to quickly re-colonize disturbed areas (Bick and Arlt 2005; Conlan and Kvitek 2005; Kuklinski et al. 2013). Thus, it can be assumed that biotic factors are of minor importance, and accordingly, we tested the null-hypothesis that consumption and bioturbation by larger organisms such as predatory crabs and burrowing lugworms have no influence on the abundance, diversity and species composition of a soft-bottom species assemblage. But, if the null-hypothesis has to be rejected, our field experiment reveals strong evidence that also biotic factors can affect coastal sedimentary marine Arctic communities.

The importance of biotic effects for shaping Arctic benthic assemblages will presumably increase when global warming and rising seawater temperature reduce the physical stress for shallow water communities at higher latitudes, due to a shorter ice-season, reduced ice coverage, lower ice thickness and less frequent iceberg scour. At the same time, higher temperature should increase the activity level of consumers and bioturbators. This may lead to an increase in the frequency of species interactions and, thus, in a higher importance of biotic control mechanisms affecting Arctic coastal communities (Weslawski et al. 2011). Therefore, our study focuses on biotic factors, which have rarely been so far considered in polar regions and which may constitute fundamental processes in a forthcoming warmer Arctic marine ecosystem.

\section{Materials and methods}

Study site

All experimental field work was conducted at Brandal (N $78^{\circ} 56.869^{\prime}$, E $011^{\circ} 51.177^{\prime}$ ), a shallow water, soft-sediment site located at the border between the middle and transitional zone on the southern shore of Kongsfjorden, West Spitsbergen. The fjord is influenced by warmer Atlantic and colder Arctic water masses and harbours a mixture of cold temperate and Arctic flora and fauna (Hop et al. 2002). While oceanographic conditions influence the outer fjord, the inner part is strongly affected by large glaciers (Svendsen et al. 2002). Icebergs and floating ice are particularly frequent during summer months (Dowdeswell and Forsberg 1992; Wlodarska-Kowalczuk and Pearson 2004). These glaciers form steep physical gradients in the water body of the fjord, especially in sedimentation rate and freshwater input (Svendsen et al. 2002; Hop et al. 2002). Thus, changes in benthic community composition and abundance from the inner to the outer fjord can be observed (Hop et al. 2002). Semidiurnal tides with a range of about $2 \mathrm{~m}$ generate tidal currents of moderate strength (Ito and Kudoh 1997). The seafloor at the study area gently slopes from the shore to a water depth of about $11 \mathrm{~m}$ before it drops to a depth of $>100 \mathrm{~m}$ (pers. comm. M. Schwanitz). Sediment type ranges from fine sand to coarse silt, and in terms of species number, the soft-bottom community at Brandal is dominated by polychaetes, molluscs and crustaceans (Folk and Ward 1957; Herrmann 2006). Close to the seafloor, mean water temperature was $5.4^{\circ} \mathrm{C}$ (pers. measurements, $\min =3.4{ }^{\circ} \mathrm{C}, \quad \max =7.0{ }^{\circ} \mathrm{C}, \quad \mathrm{HOBO}^{\circledR}$ Data Logger) during the experimental period from June to 
August 2012. A surface water salinity of 32 (Svendsen et al. 2002) indicates that Brandal is a fully marine site.

\section{Experimental design and set-up}

Using a factorial experiment with a nested design, the separate and combined effects of bioturbation and consumption on the diversity and species composition of benthic infauna communities were assessed.

The complete experimental set-up was installed at an average water depth of $7 \mathrm{~m}$ in a $9 \mathrm{~m} \times 12 \mathrm{~m}$ area on 19 June 2012 , i.e. the day when the experiment started. The experiment was terminated on 28 August 2012. Here, a total of 15 plots $(1.2 \mathrm{~m} \times 1.2 \mathrm{~m})$ were arranged in five rows, with each row containing three plots, each plot with a different bioturbation treatment (Fig. 1). Within rows, the three bioturbation treatments were randomly distributed. One bioturbation treatment excluded bioturbators by burying a black polyethylene mesh (mesh size $0.4 \mathrm{~cm} \times 0.4 \mathrm{~cm}$ ) at least $5 \mathrm{~cm}$ deep into the sediment. The mesh was fixed at its corners with 40-cm iron rods and prevents the occurrence of large bioturbators such as the lugworm Arenicola marina as shown in previous studies (Volkenborn et al. 2007). The second bioturbation treatment was used to test for possible artefacts caused by the mesh burial procedure (=procedural controls). In these procedural control plots, the top $5 \mathrm{~cm}$ of sediment was removed like in the first bioturbation treatment, but no mesh was added before the sediment was returned. The location of plots designated for the third bioturbation treatment, i.e. unmanipulated controls, was marked with $40-\mathrm{cm}$ iron rods that were pushed into the sediment at each corner of a plot. The efficacy of treatments to exclude bioturbating organisms, such as the lugworm $A$. marina, was controlled biweekly by counting the number of mounds that were generated by these animals in all 15 plots. To manipulate consumer occurrence (mainly the spider crab Hyas araneus and the dogwhelk Buccinum sp.), cylindrical cages of $35 \mathrm{~cm}$ height and $25 \mathrm{~cm}$ in diameter were fixed with three 40-cm iron rods to the sea-floor (Fig. 2). For exclusion of macrobenthic consumers, complete cages were used. These were constructed with two PVC rings $(25 \mathrm{~cm}$ in diameter) that were $35 \mathrm{~cm}$ apart. A polyethylene mesh (mesh size $0.5 \mathrm{~cm} \times 0.5 \mathrm{~cm}$ ) was wrapped around both rings and permanently fixed with cable ties. The cage top was also covered with the polyethylene mesh, while the bottom side, which was facing in the set-up to the seafloor, remained open. For a second treatment, open cages were constructed to test for cage artefacts. The top of open cages was not covered by a mesh, and three holes $(10 \mathrm{~cm} \times 10 \mathrm{~cm})$ were cut into the mesh near the bottom ring to allow consumers to enter and exit cages. As a third treatment areas without cages were used as controls; i.e. no experimental manipulation of consumer densities. Each of the three consumer treatments [(1) closed cages, (2) open cages and (3) no cages] was twofold replicated on each plot (total of 90 experimental units, Fig. 1). The minimum distance between areas designated for consumer treatments was $30 \mathrm{~cm}$ to each other and $10 \mathrm{~cm}$ to plot margins to minimize margin effects (Fig. 1).

The presence of the crab $H$. araneus was confirmed from regular catches with unbaited fish traps and direct observations in the field. However, a quantification of its density was not feasible, because of the patchy and irregular occurrence of $H$. araneus.

To get an estimate on the density of the lugworm $A$. marina as the largest bioturbating species at the study site, the mounds that were generated by A. marina were counted per square metre $(n=6)$ in randomly chosen plots near the experimental set-up on 10, 18 and 31 July 2012. Furthermore, the number of individuals of the second largest bioturbating species, the sea cucumber Chirodota laevis, was quantified from $50 \mathrm{~cm} \times 50 \mathrm{~cm}$ quadrats after sieving the top $5 \mathrm{~cm}$ of airlifted sediment on 2 and 16 August 2012 $(n=6)$. All work at the set-up and measurements were conducted by SCUBA diving.

\section{Determination of sample size and depth}

A pilot study was conducted to determine the minimum sample size needed to sample a representative number of species of the prevailing benthic community at Brandal. For this purpose, 12 samples were taken with each of two different corer sizes, i.e. 3.2 and $5.2 \mathrm{~cm}$ in diameter that were pushed $10 \mathrm{~cm}$ deep into the sediment. All corer samples were transported within $1 \mathrm{~h}$ after sampling to the marine laboratory at Ny-Ålesund. Here, all specimens were identified, and cumulative species numbers were calculated for each corer type separately using all 12 samples. Species accumulation curves were plotted for each corer size based on a random order of chosen cores. Both plots show asymptotic curvatures and indicate that, on average, $38 \%$ more species were collected with the larger than with the smaller corer type (Fig. 3). No species additions were recorded after eight or nine cores, which were sampled with the larger and smaller corer type, respectively. This suggests that eight large corers may be sufficient to generate a representative sample of the species inventory that was present at the study site.

We also determined the critical depth of sediment cores by taking corer samples of $10 \mathrm{~cm}$ depth at Brandal $(n=5)$, which were divided into two parts (upper and lower $5 \mathrm{~cm}$ ). Afterwards, the number of species and number of individuals were recorded from both parts. This study showed that $96 \%$ of all species and $98 \%$ of all individuals occurred in the upper $5 \mathrm{~cm}$ of the sediment. Consequently, all samples in this study were taken with the larger sediment corer of $5.2 \mathrm{~cm}$ diameter (sampled surface area of $21 \mathrm{~cm}^{2}$ ) that was pushed $5 \mathrm{~cm}$ deep into the sediment. 
Fig. 1 Schematic spatial arrangement of bioturbation and consumer treatments. Quadrates indicate plot margins: thick solid lines represent plots with mesh (i.e. with mat, exclusion of bioturbators), dashed lines mark procedural controls (i.e. without mat, burial disturbance), and thin solid lines indicate un-manipulated controls. Circles mark consumer treatments with closed cages (grey), open cages (black) and no cages (white). Note that scheme is not to scale

\section{$2.5 \mathrm{~m}$}
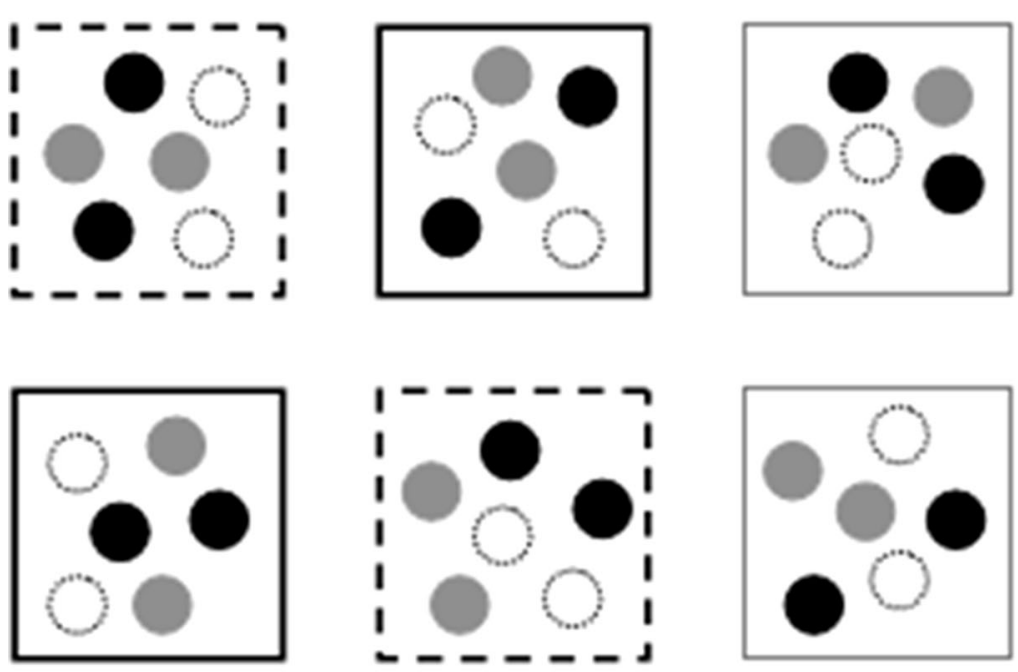
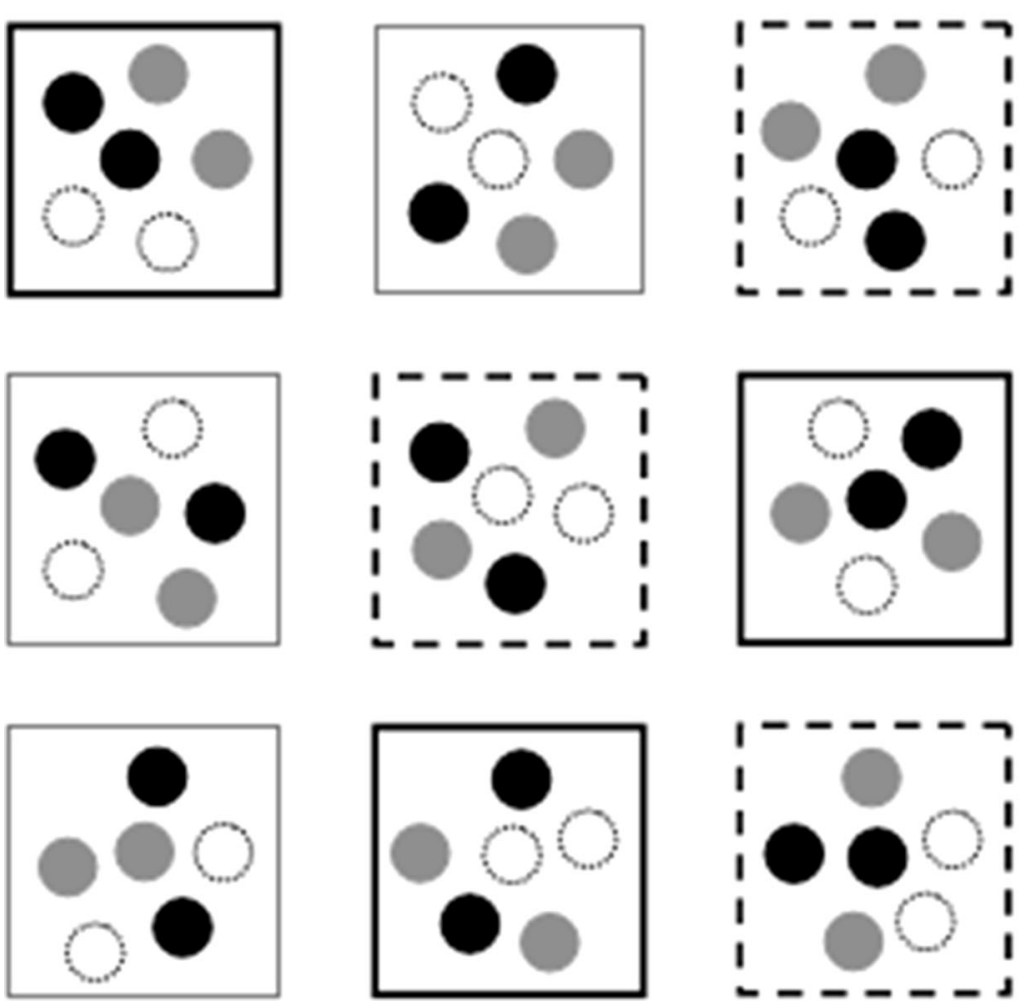

Sampling of species assemblage

Two dates for sampling of the community were scheduled. First, samples were taken 7 days after the manipulation started (26 June 2012), to test whether diversity and species composition of infauna communities were still affected from mesh burial activities. Therefore, one core was taken from uncaged areas of each plot where the sediment was disturbed (procedural control of bioturbation treatment)

and from each un-manipulated plot $(n=5)$. Plots with a buried mesh were not sampled.

Second, at the end of the 70-day experimental period ( 28 August 2012), one core was taken from each experimental unit, i.e. a total of two cores of each consumer treatment of each plot $(n=90)$. The cores were transported $\leq 2 \mathrm{~h}$ to the Marine Laboratory of Ny-Ålesund and stored for $<4$ days in a cooler at $5{ }^{\circ} \mathrm{C}$ until they were analysed. Before the analysis, samples were rinsed with filtered seawater over a 


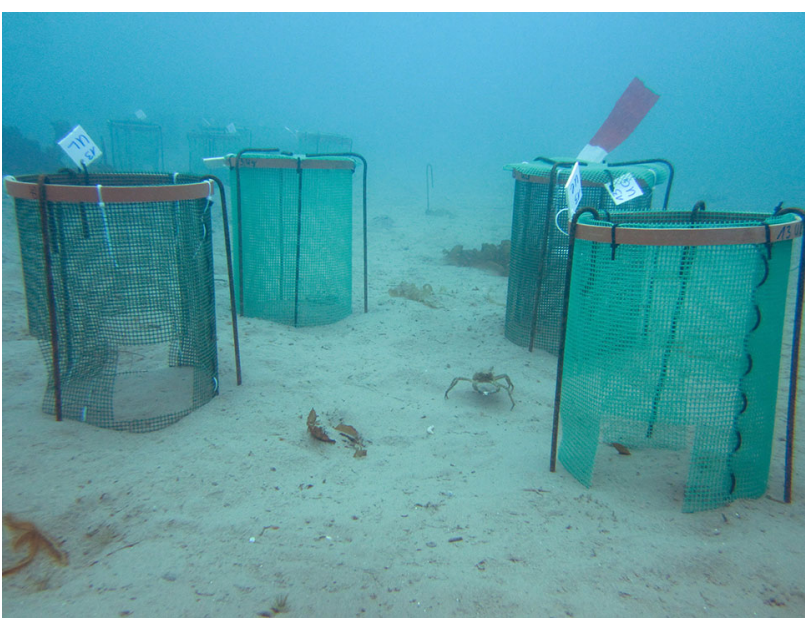

Fig. 2 Picture from the underwater set-up showing one bioturbation plot with two closed and two open cages

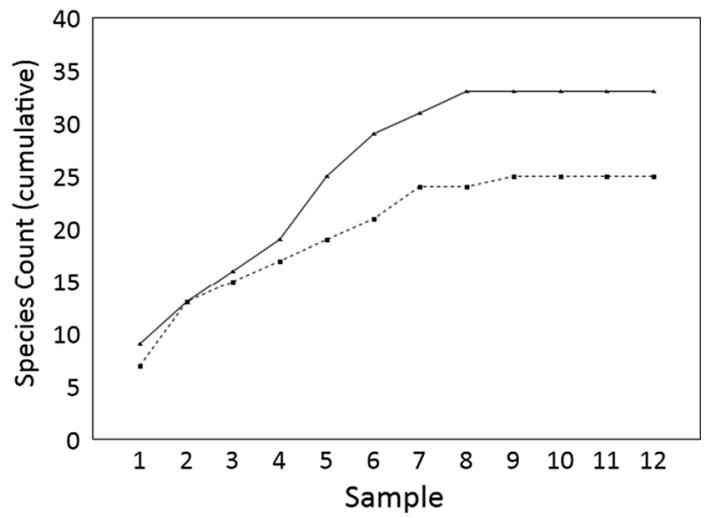

Fig. 3 Species-sample curves for benthic infauna at Brandal using two different corer sizes. The dashed line represents a corer size of $3.2 \mathrm{~cm}$, and the solid line marks a corer size of $5.2 \mathrm{~cm}$ in diameter

0.5-mm sieve and retained organisms were separated from the sediment. All living animals were counted and identified to the lowest possible taxonomic level using a stereomicroscope. The number of species and number of individuals were used to deduce species richness $(S)$, i.e. the total number of taxa, and to calculate Pielou's evenness $\left(J=H^{\prime} / \log S\right)$, where $H^{\prime}$ is the Shannon index, to describe how evenly individuals are distributed across taxa and samples. Dry mass of all organisms of each sediment core was determined on a laboratory balance to the nearest $0.001 \mathrm{~g}$ after drying the organisms in an oven at $60{ }^{\circ} \mathrm{C}$ to constant weight.

\section{Statistical analysis}

Data from the first sampling date were used to test for the effects of mesh burial activity (2 levels, fixed) on diversity and structure of infauna assemblages with Student's $t$ tests and one-way PERMANOVA, respectively $(n=5)$. Data on species richness, evenness, abundance and dry mass from the second sampling date were analysed using a threeway nested ANOVA, and data on species composition were analysed with a three-way nested PERMANOVA. In all these analyses, factors were bioturbation (three levels, fixed), consumers (three levels, fixed) and plot (fifteen levels, random). Herein, complete or sequential removal of random sources of variance from the ANOVA and PERMANOVA models, recalculation of residuals and selection of appropriate denominators were done when random sources of variance were non-significant at $\alpha \geq 0.25$ (Quinn and Keough 2002, p. 260). Prior to the analysis of data with Student's $t$ tests, normality was confirmed with a Kolmogorov-Smirnov test. For Student's $t$ tests and ANOVAs, homogeneity of variances was confirmed with Levine's and Cochran's test, respectively, and, if necessary, data (i.e. number of individuals and dry mass) were square-root-transformed to meet the assumptions. Data with heterogeneous variances after transformation (i.e. number of A. marina mounds) were analysed with Kruskal-Wallis test. Following the recommendation by Clarke and Warwick (2001), data used in PERMANOVAs were routinely square-root-transformed prior to the calculation of Bray-Curtis similarity indices to account for contribution of rarer species to similarity. The Monte Carlo $p$ value was added for PERMANOVAs using less than the selected number of 9,999 permutations. MDS plots were generated to illustrate PERMANOVA results, and a SIMPER analysis was used to determine the contribution of taxa to significant differences in species composition among treatments.

\section{Results}

Species occurrence

In total, 73 invertebrate taxa were identified at Brandal during this study in summer 2012. Four of those species have not been reported from Svalbard so far, i.e. the brittlestar Ophiura albida, the hermit crab Anapagurus chiroacanthus and the polychaete worms Clymenura tricirrata and Ophelia rathkei. Six additional species are known from Svalbard, but have not been reported from Kongsfjorden, namely the gastropods Onoba mighelsii and Retusa obtusa, the bivalve Mya arenaria, the crustacean Caprella linearis as well as the polychaete worms Arenicola marina and Pygospio cf. elegans (Table 1). The community at Brandal was dominated by polychaetes (26 species), followed by crustaceans (14 species) and bivalves (14 species) representing together $77 \%$ of the total species number. The five most abundant species in unmanipulated experimental units during the final sampling at the end of August were 
Table 1 List of taxa identified in samples collected in summer 2012 at Brandal

Platyhelminthes

Platyhelminthes indet.

Nematoda

Nematoda indet.

Nemertea

Nemertea indet. 1

Nemertea indet. 2

Cephalorhynchus

Priapulida

Priapulus caudatus (Lamarck, 1816)

Cnidaria

Anthozoa

Edwardsia fusca (Danielssen, 1890)

Echinodermata

Holothuroidea

Chiridota laevis (O. Fabricius, 1780)

Ophiuroidea

Ophiura albida (Forbes, 1839) ${ }^{\mathrm{a}}$

Mollusca

Bivalvia

Astarte sulcata (da Costa, 1778)

Axinopsida orbiculata (G. O. Sars, 1878)

Crenella decussata (Montagu, 1808)

Cyrtodaria siliqua (Spengler, 1793)

Hiatella arctica (Linnaeus, 1767)

Bivalvia indet

Liocyma fluctuosa (Gould, 1841)

Macoma sp.

Montacuta spitzbergensis (Knipowitsch, 1901)

Mya arenaria (Linnaeus, 1758) ${ }^{\mathrm{b}}$

Mya truncata (Linnaeus, 1758)

Pandora glacialis (Leach in Ross, 1819)

Serripes groenlandicus (Mohr, 1786)

Thracia sp.

Gastropoda

Buccinum sp.

Cylichna sp.

Lunatia pallida (Broderip \& Sowerby I, 1829)

Margarites sp.

Naticidae sp.

Onoba mighelsii (Stimpson, 1851) ${ }^{\mathrm{b}}$

Retusa obtusa (Montagu, 1803) ${ }^{\mathrm{b}}$

Skenea sp.

Arthropoda

Arachnida

Acarina indet.

Crustacea, Malacostraca

Anapagurus chiroacanthus (Lilljeborg, 1856) ${ }^{\mathrm{a}}$

Caprella linearis (Linnaeus, 1767) ${ }^{\mathrm{b}}$
Table 1 continued

Crassicorophium crassicorne (Bruzelius, 1859)

Eualus gaimardi gaimardii (Edwards, 1837)

Gammarus sp.

Hyas araneus (Linnaeus, 1758)

Lamprops fuscatus (Sars, 1865)

Monoculodes packardi (Boeck, 1871)

Orchomenella minuta (Krøyer, 1846)

Pleustes panoplus (Krøyer, 1838)

Priscillina herrmanni (d'Udekemd'Acoz, 2006)

Synidotea nodulosa (Krøyer, 1846)

Thysanoessa inermis (Krøyer, 1846)

Crustacea, Maxillopoda

Copepoda indet.

Crustacea, Ostracoda

Ostracoda indet.

Annelida

Polychaeta

Arenicola marina (Linnaeus, 1758) ${ }^{\mathrm{b}}$

Capitella capitata (Fabricius, 1780)

Chaetozone setosa (Malmgren, 1867)

Clymenella sp.

Clymenura tricirrata (Arwidsson, 1906) ${ }^{\mathrm{a}}$

Clymenura sp.

Dipolydora quadrilobata (Jacobi, 1883)

Euchone analis (Krøyer, 1865)

Glycera sp.

Maldanidae indet. 1

Maldanidae indet. 2

Maldanidae indet. 3

Maldanidae indet. 4

Marenzelleria wireni (Augener, 1913)

Nephtys sp.

Ophelia rathkei (McIntosh, 1908) ${ }^{\mathrm{a}}$

Ophelina sp.

Owenia fusiformis (Delle Chiaje, 1844)

Pholoe assimilis (Oersted, 1845)

Phyllodoce groenlandica (Oersted, 1842)

Praxillella sp.

Pygospio cf. elegans (Claparède, 1863) ${ }^{\mathrm{b}}$

Scalibregma sp.

Spio armata (Thulin, 1957)

Terebellidae juv.

Travisia forbesii (Johnston, 1840)

Hemichordata

Enteropneusta

Enteropneusta indet.

${ }^{a}$ Taxon not reported for Svalbard

b Taxon not reported for Kongsfjorden, but for Svalbard, according to Gulliksen et al. 1999; Kaczmarek et al. 2005; Laudien et al. 2007; Włodarska-Kowalczuk 2007; Voronkov et al. 2013 
Table 2 Three-way nested ANOVAs analysing the effects of bioturbation on species richness, number of infauna individuals, evenness and dry mass between different consumer treatments

\begin{tabular}{|c|c|c|c|c|c|c|c|c|c|}
\hline \multirow[t]{2}{*}{ Source } & \multicolumn{4}{|c|}{ Species richness } & \multicolumn{5}{|c|}{ \# Individuals } \\
\hline & $d f_{\text {pooled }}$ & $F$ & $p$ & $\mathrm{MQ}_{\mathrm{den}}$ & $d f$ & & $F$ & $p$ & $\mathrm{MQ}_{\mathrm{den}}$ \\
\hline Bioturbation, B & 2 & 4.55 & 0.034 & $\operatorname{Plot}(\mathrm{B})$ & 2 & & 20.34 & $>0.001$ & $\operatorname{Plot}(\mathrm{B})$ \\
\hline Consumption, C & 2 & 0.40 & 0.672 & Pooled & 2 & & 1.50 & 0.234 & $\mathrm{C} \times \operatorname{plot}(\mathrm{B})$ \\
\hline $\mathrm{B} \times \mathrm{C}$ & 4 & 1.62 & 0.179 & Pooled & 4 & & 1.14 & 0.350 & $\mathrm{C} \times \operatorname{plot}(\mathrm{B})$ \\
\hline $\operatorname{Plot}(\mathrm{B})$ & 12 & 2.26 & 0.018 & Pooled & 12 & & 1.77 & 0.084 & Residual \\
\hline $\mathrm{C} \times \operatorname{plot}(\mathrm{B})$ & & 0.96 & 0.537 & Residual & 24 & & 1.60 & 0.087 & Residual \\
\hline Residual & 45 & & & & 45 & & & & \\
\hline Pooled & 69 & & & & No & oling & & & \\
\hline \multirow[t]{2}{*}{ Source } & \multicolumn{4}{|c|}{ Evenness } & & \multicolumn{4}{|c|}{ Dry mass } \\
\hline & $d f_{\text {pooled }}$ & $F$ & $p$ & $M Q_{\text {den }}$ & & $d f_{\text {pooled }}$ & $F$ & $p$ & $\mathrm{MQ}_{\mathrm{den}}$ \\
\hline Bioturbation, B & 2 & 1.46 & 0.238 & Pooled & & 2 & 4.95 & 0.009 & Pooled \\
\hline Consumption, C & 2 & 1.62 & 0.205 & Pooled & & 2 & 2.70 & 0.074 & Pooled \\
\hline $\mathrm{B} \times \mathrm{C}$ & 4 & 0.80 & 0.542 & Pooled & & 4 & 0.33 & 0.860 & Pooled \\
\hline $\operatorname{Plot}(\mathrm{B})$ & & 1.014 & 0.446 & Pooled & & & 1.28 & 0.293 & Pooled \\
\hline $\mathrm{C} \times \operatorname{plot}(\mathrm{B})$ & & 0.98 & 0.512 & Residual & & & 0.47 & 0.976 & Residual \\
\hline Residual & 45 & & & & & 45 & & & \\
\hline Pooled & 81 & & & & & 81 & & & \\
\hline
\end{tabular}

Elimination of random factors and recalculation of residuals were done after verifying that the variance of random factor(s) $=0$, i.e. not significant at $\alpha \geq 0.25$, where used denominator mean square $\left(\mathrm{MQ}_{\mathrm{den}}\right)$ is shown for each source of variation in columns $\mathrm{MQ}_{\mathrm{den}}$. Pooled term $=$ random factor(s) + Residual, $d f_{\text {pooled }}=$ degrees of freedom after elimination of random factor(s), significant results at $\alpha \leq 0.05$ in bold, $n=5$

the cumacean Lamprops fuscatus (5,510 ind. $\mathrm{m}^{-2}$ ), the crustacean Crassicorophium crassicorne $\left(8,700\right.$ ind. $\left.\mathrm{m}^{-2}\right)$, the polychaetes Pygospio cf. elegans $\left(4,524\right.$ ind. $\left.\mathrm{m}^{-2}\right)$ and Euchone analis $\left(2,033\right.$ ind. $\left.\mathrm{m}^{-2}\right)$ and the bivalve Crenella decussata $\left(2,666\right.$ ind. $\left.\mathrm{m}^{-2}\right)$.

The density of A. marina mounds as well as of the sea cucumber $C$. laevis was not significantly different between sampling dates (A. marina mounds: one-way ANOVA, $F_{2,15}=0.98, p=0.397$; $C$. laevis density: $t$ test: $t_{10}=0.70$, $p=0.498)$. The average density of $A$. marina mounds per $0.25 \mathrm{~m}^{-2}$ was $2.9( \pm 2.1 \mathrm{SD})$, while the number of individual C. laevis was, on average, $18.1( \pm 6.5 \mathrm{SD})$ per $0.25 \mathrm{~m}^{-2}$.

\section{Bioturbation and consumption effects}

The number of individuals, species richness and dry mass, but not evenness was significantly different between bioturbation treatments (Table 2). There were significantly more species (on average $25 \%$ ), two times, on average, more individuals, and a higher dry mass (on average $73 \%$ ) recorded from plots with mats than from un-manipulated plots. Yet, neither species richness, nor the number of individuals, evenness and dry mass were significantly different between un-manipulated plots (no mat) and burial controls (Fig. 4). Furthermore, species richness and the number of individuals, but not dry mass were significantly higher by, on average, 28 and $85 \%$, respectively, in plots with mats than in burial controls. A significant plot effect for species richness indicates that the number of species was different across the experimental area. For the interpretation of treatment effects, it is, however, important that this patchiness neither obscured the effects of bioturbation on species richness nor was the "consumer $\times$ plot (bioturbation)" interaction significant (Table 2), indicating consistency in consumer manipulations on species richness across the experimental set-up.

Consumer treatments were without effect on any of the four response variables tested, and this result was independent of bioturbation treatments, as indicated by a non-significant consumer $\times$ bioturbation interaction (Table 2; Fig. 4).

Species composition was significantly affected by bioturbation but not by consumers (Table 3). The composition of the benthic assemblages from un-manipulated plots and procedural controls was not significantly different from each other, but both were significantly different in their composition of encountered species to plots with mats (Fig. 5). Species were generally negatively affected by bioturbation (Table 4). The cumacean L. fuscatus, the amphipod $C$. crassicorne, the polychaetes $P$. cf. elegans and $E$. analis, and the bivalve $C$. decussata contributed strongest to the observed differences in species composition between bioturbation treatments (Table 4). 
Fig. 4 Mean (+SEM, standard error of the mean) species richness (a), number of individuals (b), evenness (c) and dry weight (d) of infauna assemblages for different combinations of bioturbation and consumer treatments (per $21 \mathrm{~cm}^{2}$ sampled surface area). White, black and grey bars indicate consumer treatments without cages (no cage), open cages (pc, i.e. procedural control) and closed cages (cage), respectively.

Bioturbation treatments are unmanipulated plots (no mat), no mat but burial activity (burial control) and bioturbator exclusion (with mat). Statistically significant differences in bioturbation treatments are marked by different letters
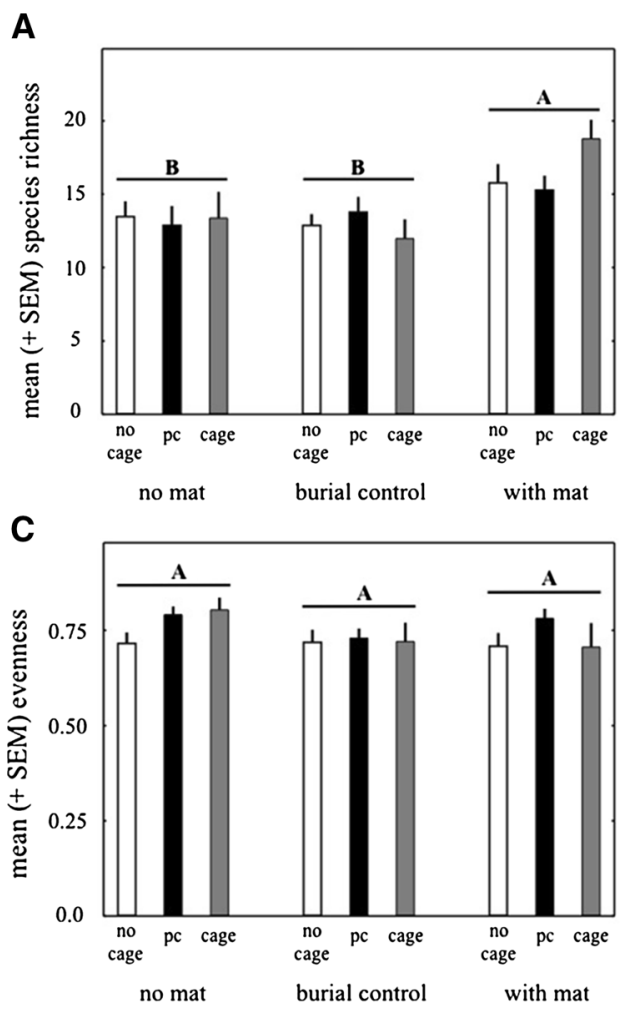

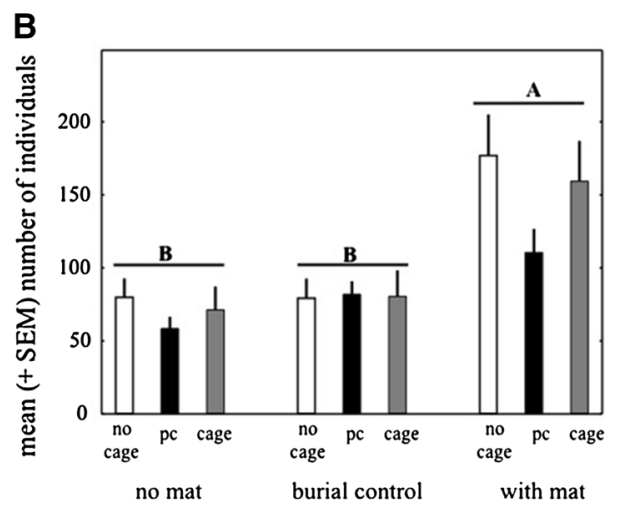

D

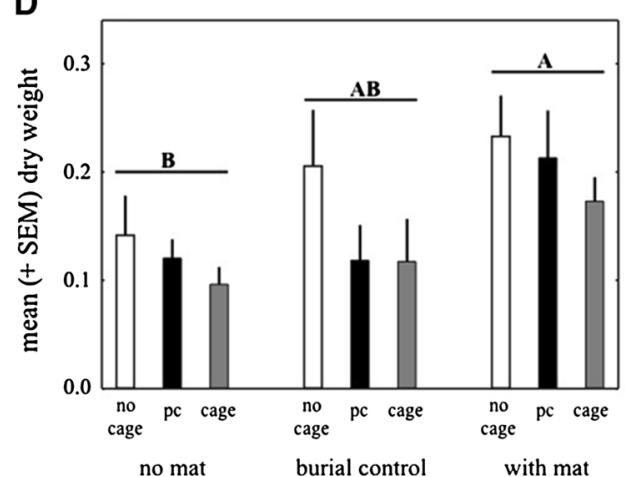

Table 3 Results of three-way nested PERMANOVA analysing the effects of bioturbation and consumer treatments on species composition

\begin{tabular}{lccccrrr}
\hline Source & $d f_{\text {pooled }}$ & MQ & Pseudo-F & $p$ & Permutations & $p($ MC) & MQden \\
\hline Bioturbation, B & 2 & $4,273.6$ & 2.88 & $\mathbf{0 . 0 0 5}$ & 9,514 & $<0.001$ & Plot(B) \\
Consumption, C & 2 & $1,408.2$ & 1.49 & 0.056 & 9,900 & 0.072 & Pooled \\
B $\times$ C & 4 & $1,035.8$ & 1.10 & 0.306 & 9,859 & 0.312 & Pooled \\
Plot(B) & 12 & $1,482.1$ & 1.57 & $<\mathbf{0 . 0 0 1}$ & 9,758 & $<0.001$ & Pooled \\
C $\times$ plot(B) & & 947.8 & 1.00 & 0.477 & 9,726 & Residual \\
Residual & 45 & 943.7 & & & & \\
Pooled & 69 & & & & &
\end{tabular}

Elimination of random source(s) of variance and recalculation of residuals were done after verifying that the variance of random source(s) of variance $=0$, i.e. not significant at $\alpha \geq 0.25$, where used denominator mean square $\left(\mathrm{MQ}_{\mathrm{den}}\right)$ is shown for each source of variation in columns $\mathrm{MQ}_{\mathrm{den}}$. Pooled term $=$ random source(s) of variance + Residual, $d f_{\text {pooled }}=$ degrees of freedom after elimination of random source(s). Permutations $=$ number of possible permutations, $p(\mathrm{MC})=$ probability value obtained from Monte Carlo analysis, significant results at $\alpha \leq 0.05$ in bold, $n=5$

\section{Control of experimental treatments}

\section{Mesh burial activity}

Seven days after experimental manipulations started, significantly fewer individuals were found in procedural controls than in un-manipulated plots (Table 5). In contrast, evenness was significantly higher in procedural controls than in un-manipulated plots (Table 5). However, significant differences between both treatments were neither found for species richness (Table 5) nor for the composition of species (one-way PERMANOVA with 126 unique permutations: pseudo- $\left.F_{1,8}=1.68, p=0.076 ; p(\mathrm{MC})=0.157\right)$, indicating that mesh burial at the beginning of the experiment was followed by a rapid re-colonization.

\section{Effectiveness of buried mesh}

The average number of mounds occurring in the different bioturbation treatments was not significantly different between procedural controls $(4 \pm 1.2$ mounds; $\min =2$, $\max =7)$ and un-manipulated plots $(6 \pm 3.6$ mounds, $\min =2, \max =15$ ). In both treatments, however, significantly more mounds were found than on exclusion 


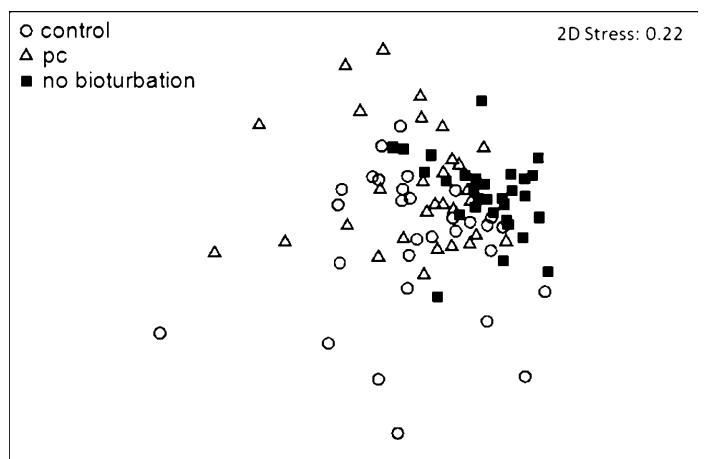

Fig. 5 MDS plot illustrating levels of similarity of infauna assemblages between bioturbation treatments. Circles $=$ control, un-manipulated controls; triangles $=\mathrm{pc}$, procedural controls; squares $=$ no bioturbation, with mat

plots, where no mounds could be detected (Kruskal-Wallis test; $\left.H_{2}: 9.63, p=0.008\right)$. Thus, the buried mesh completely excluded larger bioturbating organisms such as the lugworm A. marina from experimental plots, while the activities associated with the burial of a mesh did not affect the biotubators.

\section{Discussion}

The burial of a mesh significantly reduced the activity of burrowing organisms as indicated by the lower number of mounds in plots with than without mesh. These mounds were caused by the lugworm A. marina, which we encountered as the largest bioturbating species at the study site. This reduction in bioturbation activity caused an increase in
Table 5 Mean $( \pm$ SEM) values of response variables and results from $t$ tests for different bioturbation treatments recorded 7 days after the manipulation started $(n=5)$

\begin{tabular}{llllll}
\hline & \multicolumn{4}{l}{ Burial disturbance } \\
\cline { 2 - 6 } & Control & PC & $d f$ & $t$ & $p$ \\
\hline Richness & $13.00( \pm 0.8)$ & $11.6( \pm 0.8)$ & 8 & 1.20 & 0.264 \\
\# Individuals & $78.00( \pm 13.3)$ & $36.60( \pm 4.7)$ & 8 & 2.94 & $\mathbf{0 . 0 1 9}$ \\
Evenness & $0.73( \pm 0.04)$ & $0.86( \pm 0.02)$ & 8 & -2.69 & $\mathbf{0 . 0 2 8}$ \\
Wet weight & n.a. & n.a. & & & \\
\hline
\end{tabular}

Significant results in bold font. n.a. $=$ not applicable, $\mathrm{PC}=$ procedural control of burial activity

the number of individuals, species richness and dry weight of the benthic community in plots where a mesh was present. Additionally, bioturbator exclusion significantly changed the species composition of the soft-bottom community. In contrast, species diversity or composition of the softbottom community was not significantly different between areas with and without cages, indicating missing consumer effects of epibenthic predators, which were also independent of bioturbation treatments. Neither the activities associated with the burial of a mesh, nor the presence of cages seems to affect community responses permanently.

Effects and occurrence of bioturbators

Placing a mesh into the bottom to inhibit bioturbation in soft-bottom habitats was also applied in different studies conducted in tropical and temperate regions. This method was especially successful to prevent the sediment-

control $=$ unmanipulated plots, mat $=$ plots with a buried mat to exclude the bioturbator Arenicola marina)

Table 4 Mean $( \pm \mathrm{SD})$ number of individuals of species constituting $>80 \%$ to total density in samples $\left(21 \mathrm{~cm}^{2}\right)$ of the three bioturbation treatments $\quad$ burial $=$ procedural control of mat burial,

\begin{tabular}{|c|c|c|c|c|c|c|}
\hline Species & Burial & Control & Mat & Procedural effect & Bioturbation effect & $\%$ \\
\hline Lamprops fuscatus & $22.6( \pm 16.4)$ & $11.6( \pm 10.6)$ & $48.9( \pm 74.2)$ & no & - & 25.7 \\
\hline Crassicorophium crassicorne & $16.8( \pm 12.7)$ & $18.3( \pm 12.6)$ & $22.0( \pm 11.5)$ & no & - & 12.3 \\
\hline Euchone analis & $2.9( \pm 2.9)$ & $4.3( \pm 5.4)$ & $16.1( \pm 11.8)$ & no & - & 11.3 \\
\hline Pygospio cf. elegans & $14.2( \pm 24.2)$ & $9.5( \pm 16.8)$ & $14.7( \pm 13.1)$ & no & - & 10.7 \\
\hline Crenella decussata & $4.4( \pm 4.3)$ & $5.6( \pm 4.7)$ & $15.7( \pm 13.0)$ & no & - & 10.6 \\
\hline Ostracods & $5.6( \pm 4.5)$ & $6.6( \pm 6.7)$ & $7.1( \pm 5.9)$ & no & - & 5.7 \\
\hline Copepods & $1.2( \pm 1.3)$ & $2.1( \pm 2.9)$ & $4.1( \pm 4.1)$ & no & - & 3.2 \\
\hline Nemertini spec. & $2.6( \pm 3.0)$ & $1.8( \pm 1.5)$ & $3.1( \pm 2.3)$ & no & - & 2.3 \\
\hline Ophelina spec. & $0.7( \pm 1.2)$ & $0.6( \pm 1.0)$ & $2.6( \pm 2.0)$ & no & - & 2.2 \\
\hline Ophiura albida & $1.4( \pm 1.4)$ & $1.0( \pm 1.5)$ & $2.5( \pm 2.4)$ & no & - & 2.1 \\
\hline Nematods & $1.6( \pm 2.2)$ & $1.3( \pm 1.6)$ & $2.0( \pm 1.8)$ & no & - & 1.6 \\
\hline Gammarus sp. & $0.5( \pm 0.8)$ & $0.6( \pm 1.2)$ & $1.2( \pm 1.8)$ & no & - & 1.2 \\
\hline
\end{tabular}

The direction of effects (procedural effect $=$ burial vs. control; bioturbation effect $=$ mat vs. control) is given as $-=$ negative and no $=$ no contribution. \% indicates the percent contribution of a species to the detected significant bioturbation effect on species composition $(n=5)$ 
reworking activity of larger bio-engineering organisms such as burrowing crabs and lugworms without causing experimental artefacts on smaller organisms occurring in higher sediment layers above the mat (e.g. Dittmann 1996; Volkenborn and Reise 2006, 2007; González-Ortiz et al. 2014).

At our study site, the mean density of the lugworm $A$. marina was about five individuals per $\mathrm{m}^{2}$ (quantified by counting the faecal casts on the experimental plots without a mesh). This is considerably lower than known from most intertidal flats in the Wadden Sea (Beukema 1976; Volkenborn and Reise 2006, 2007), but similar to densities found on offshore flood delta shoals near the island of Sylt in the south-eastern North Sea (Lackschewitz and Reise 1998) and in the western Baltic Sea (Brey 1991). The latter studies reveal that already a low lugworm density may structure benthic assemblages, because their feeding pits and faecal mounds represent unstable structures avoided by many infauna organisms. On the other hand, they may promote the aggregation of specific species such as copepods, platyhelminths, nemertines and polychaete worms (Reise 2002). Lugworm activity does not only cause sediment instability, but may also change sediment properties such as particle composition, content of organic matter, sulphide concentrations and sediment permeability (Volkenborn and Reise 2006; Volkenborn et al. 2007; Wendelboe et al. 2013). Thus, sediment-mediated indirect effects may have similar importance for benthic species assemblages as the direct physical disturbance caused by $A$. marina. For example, Woodin (1986) and Woodin et al. (1995) show that alterations in sediment properties may affect settlement behaviour of polychaetes and bivalves.

Surprisingly, to our knowledge the lugworm A. marina was not detected in other studies conducted at our site and was generally rarely found in Kongsfjorden (e.g. Laudien et al. 2007; Wlodarska-Kowalczuk pers. communication). This is presumably due to methodical constrains. Largesized lugworms can dig their burrows as deep as $50 \mathrm{~cm}$ (Lackschewitz and Reise 1998). Therefore, it is difficult to collect them with traditional sampling gear like a Van Veen grab or an airlift system, which do not penetrate deep enough into the sediment. Instead, live A. marina were collected in this study by divers digging with their hands deep into the sediment. We found only comparatively large-sized individuals of about $20 \mathrm{~cm}$ in length at our study site but no small or juvenile lugworms. The absence of juvenile lugworms in areas with their adult conspecifics is known from temperate regions, too. There, it is assumed that juvenile A. marina suffer from physical disturbances and sediment property changes caused by their adult conspecifics resulting in different spatial usage of the habitat by juvenile and adult lugworms (Reise 1985; Lackschewitz and Reise 1998). The adult A. marina at our study site may have immigrated from nursery grounds outside the study area. Such active migration behaviour by lugworms increasing in size to sites dominated by adults is assumed for the Wadden Sea (Lackschewitz and Reise 1998). In Kongsfjorden, however, small-sized A. marina were also rarely detected outside our study site despite their lesser deep burrows that allows sampling with, e.g. a box corer. Thus, it remains unclear whether the absence of juvenile lugworms was due to unknown breeding areas or to sporadic recruitment events, which may not occur every year. High inter-annual variations in recruitment success are generally observed in multiyear-living soft-bottom invertebrates of higher latitudes (Varfolomeeva and Naumov 2013). Although the reason for this variability is often unknown, especially post-settlement factors such as winter mortality of juveniles seem to play a major role (Maximovich and Guerassimova 2003; Strasser et al. 2003; Yakovis et al. 2013).

In our experiment, the tube-building polychaete worms $E$. analis and $P$. cf. elegans, the cumacea Lamprops fuscatus, the amphipod $C$. crassicorne, and the bivalve $C$. decussata contributed strongest to the community structure differences between areas with and without A. marina. On average, all five species showed higher abundances on plots with a buried mesh. This strongly suggests that they benefit from the lugworm exclusion resulting in less disturbance, higher sediment stability and increased availability of organic material (Volkenborn and Reise 2007; Volkenborn et al. 2009). Similar patterns were found in lugworm exclusion experiments conducted in temperate regions. There, the spionid polychaete $P$. elegans, for example, showed higher densities at exclusion sites (Wilson 1991; Flach 1992; Volkenborn and Reise 2006). These small-sized polychaete worms are often opportunistic species with high reproduction and recruitment rates (Beukema et al. 1999; Bick and Arlt 2005), and their life strategy may explain the fast and dense colonization of our experimental plots where A. marina was absent. Already after only 70 days, the results of this colonization were obvious.

\section{Effects and occurrence of consumers}

Predation is a key factor affecting species occurrence and population dynamics in many marine shallow soft-bottom ecosystems (e.g. Ambrose 1984; Reise 1985; Wilson 1991; Olafsson et al. 1994; Strasser 2002; Quijon and Snelgrove 2005). Only few exceptions are known in which consumption seems to be of minor importance (e.g. Hall et al. 1990). Therefore, it was surprising that the exclusion of epibenthic consumers showed no effect on the species community in our cage experiment performed in an Arctic fjord. It might be that generally, the abundance of 
consumers was too low to cause significant effects on the prey densities outside the cages. Indeed, despite regular detections of crabs and predatory gastropods at the study site, consumer densities showed high spatial and temporal variability (own observations), which impeded an accurate quantification of predator density. An estimation of the activity of the spider crab $H$. araneus during the experimental period indicates that crab abundance is far less than one individual per square metre. This is much lower than crab density in sedimentary environments where predation causes strong effects on the benthic community (e.g. Reise 1985; Beukema 1991). We have no information on the density of other highly mobile epibenthic predator species, such as shrimps and fish, but according to our results their effects on the soft-bottom species community seem to be negligible.

Many invertebrate benthic consumers are not obligate predators, but have an opportunistic and omnivorous feeding behaviour. The shore crab Carcinus maenas, for example, is an important and widespread predator on Atlantic shorelines, which affects many invertebrate prey populations, but also feeds on carrion and algae (Baeta et al. 2006; Pickering and Quijón 2011). Likewise, necrophagous feeding is also known for the spider crab $H$. araneus (Legezynska et al. 2000; Guijarro Garcia et al. 2006; Markowska et al. 2008). Another example is the gastropod Buccinum undatum, which only feeds on living blue mussels after a starvation period of several weeks, because whelks prefer consuming injured or recently died mussels (Thompson 2002). At our study site, mean total abundance of all macrobenthic invertebrate species was about 45,000 ind. $\mathrm{m}^{-2}$. This is quite high compared to many other shallow soft-bottom ecosystems from tropical to boreal regions, where mean density ranges from 1000 to 20,000 ind. $\mathrm{m}^{-2}$ (Lackschewitz and Reise 1998; Dittmann and Vargas 2001; Michaelis and Wolff 2001; Varfolomeeva and Naumov 2013). In our investigation, the high abundance of short-living organisms in the upper sediment layer area implies a high natural mortality rate leading to plentiful carcasses of relatively small organisms at the bottom (Legezynska et al. 2000). The potential high availability of dead invertebrates may explain the missing predatory effects in our field experiment. It is very likely that many omnivorous consumers prefer this easy accessible food source, such as the scavenging whelk Buccinum sp., which we observed regularly at the study site.

\section{Conclusions}

Physical disturbance by, e.g. ice scouring is an important factor affecting species occurrence and community dynamics in Arctic shallow soft-bottom systems. Our results reveal that biotic factors such as bioturbation by the sediment-reworking lugworm A. marina may also play an important role in structuring benthic species assemblages, although investigations on the large-scale spatial distribution of invertebrate bioturbators are very rare in Arctic marine soft-bottom communities. Unexpectedly, our experiment indicates that predatory effects seem to be negligible. However, it is assumed that biotic interactions including predation will become of higher importance in the Arctic due to climate change. Rising temperatures cause a decrease in physical disturbance by ice and a northward expansion and higher abundances of many boreal species (Weslawski et al. 2011 and references therein). For example, benthic predatory crabs such as Cancer pagurus and H. araneus show increasing densities at the Norwegian and western Svalbard coast, respectively (Woll et al. 2006; Berge et al. 2009; Fagerli et al. 2014). Due to higher consumer occurrence, we expect that new predator-prey interactions will develop in the future. They may alter existing structures and dynamics of benthic communities in the Arctic. To unravel the underlying processes of these changes, a manipulative experimental approach, as used in this study, represents an appropriate and important tool, which should be applied more often in Arctic marine soft-bottom research.

Acknowledgments This work was performed at the International Arctic Environmental Research and Monitoring Facility at Ny-Ålesund, Spitsbergen, Norway. We thank Christian Wiencke for his great support. We are grateful for logistic support by the AWIPEV and the AWI diving group, in particular, Max Schwanitz for indispensable technical consultation and support. Underwater field assistance by Kai Schwalfenberg and Florian Sprung is acknowledged. Comments by D. Lackschewitz, P. Renaud, G. Veit-Köhler, M. Greenacre and one anonymous reviewer greatly improved an earlier version of the manuscript. We thank Lilo Herre for her help in the organization of our expedition.

\section{References}

Ambrose WG (1984) Role of predatory infauna in structuring marine soft-bottom communities. Mar Ecol Prog Ser 17:109-115

Ambrose WG, Leinaas HP (1988) Intertidal soft-bottom communities on the west coast of Spitsbergen. Polar Biol 8:393-395

Baeta A, Cabral HN, Marques JC, Pardal MA (2006) Feeding ecology of the green crab, Carcinus maenas, (L., 1758) in a temperate estuary, Portugal. Crustaceana 79:1181-1193

Berge J, Renaud PE, Eiane K, Gulliksen B, Cottier FR, Varpe O, Brattegard T (2009) Changes in the decapod fauna of an Arctic fjord during the last 100 years (1908-2007). Polar Biol 32:953-961

Berkenbusch K, Rowden AA, Probert PK (2000) Temporal and spatial variation in macrofauna community composition imposed by ghost shrimp Callianassa filholi bioturbation. Mar Ecol Prog Ser 192:249-257

Beuchel F, Gulliksen B (2008) Temporal patterns of benthic community development in an Arctic fjord (Kongsfjorden, Svalbard): results of a 24-year manipulation study. Polar Biol 31:913-924 
Beukema JJ (1976) Biomass and species richness of the macrobenthic animals living on the tidal flats of the Dutch Wadden Sea. Neth J Sea Res 10:236-261

Beukema JJ (1991) The abundance of shore crabs Carcinus maenas (L.) on a tidal flat in the Wadden Sea after cold and mild winters. J Exp Mar Biol Ecol 153:97-113

Beukema JJ, Flach EC, Dekker R, Starink M (1999) A long-term study of the recovery of the macrozoobenthos on large defaunated plots on a tidal flat in the Wadden Sea. J Sea Res 42: 235-254

Bick A, Arlt G (2005) Intertidal and subtidal soft-bottom macro- and meiofauna of the Kongsfjord (Spitsbergen). Polar Biol 28: $550-557$

Brey T (1991) The relative significance of biological and physical disturbance: an example from intertidal and subtidal communities. Estuar Coast Shelf Sci 33:339-360

Cadée GC (2001) Sediment dynamics by bioturbating organisms. In: Reise K (ed) Ecological comparisons of sedimentary shores. Springer, Berlin, pp 128-148

Clarke KR, Warwick RM (2001) Change in marine communities: an approach to statistical analysis and interpretation, 2nd edn. Plymouth

Conlan KE, Kvitek RG (2005) Recolonization of soft-sediment ice scours on an exposed Arctic coast. Mar Ecol Prog Ser 286:21-42

Dittmann S (1996) Effects of macrobenthic burrows on infaunal communities in tropical tidal flats. Mar Ecol Prog Ser 134: $119-130$

Dittmann S, Vargas JA (2001) Tropical tidal flat benthos compared between Australia and Central America. In: Reise K (ed) Ecological comparisons of sedimentary shores. Ecological studies 151. Springer, Berlin, pp 275-293

Dowdeswell JA, Forsberg CF (1992) The size and frequency of icebergs and bergy bits derived from tidewater glaciers in Kongsfjorden, northwest Spitsbergen. Polar Res 11:81-91

Fagerli CW, Norderhaug KM, Christie H, Pedersen MF, Fredriksen S (2014) Predators of the destructive sea urchin Strongylocentrotus droebachiensis on the Norwegian coast. Mar Ecol Prog Ser 502:207-218

Flach EC (1992) Disturbance of benthic infauna by sedimentreworking activities of the lugworm Arenicola marina. Neth $\mathrm{J}$ Sea Res 30:81-89

Flach EC (2003) The separate and combined effects of epibenthic predation and presence of macro-infauna on the recruitment success of bivalves in shallow soft-bottom areas on the Swedish west coast. J Sea Res 49:59-67

Folk RL, Ward WC (1957) Brazos River Bar: a study in the significance of grain size parameters. J Sediment Petrol 27:3-26

González-Ortiz V, Alcazar P, Vergara JJ, Pérez-Lloréns JL, Brun FG (2014) Effects of two antagonistic ecosystem engineers on infaunal diversity. Estuar Coast Shelf Sci 139:20-26

Guijarro Garcia E, Ragnarsson SA, Eiriksson H (2006) Effects of scallop dredging on macrobenthic communities in west Iceland. ICES J Mar Sci 63:434-443

Gulliksen B, Palerud R, Brattegard T, Sneli J-A (1999) Distribution of benthic macro-organisms at Svalbard (including Bear Island) and Jan Mayen. Research Report for DN 1999-4. Directorate for Nature Management, Trondheim, Norway

Gutt J (2001) On the direct impact of ice on marine benthic communities, a review. Polar Biol 24:553-564

Hall SJ, Raffaelli D, Robertson MR, Basford DJ (1990) The role of the predatory crab, Liocarcinus depurator, in a marine food web. J Anim Ecol 59:421-438

Herrmann M (2006) Makrozoobenthos-Gemeinschaften arktischer Weichböden: Struktur und Bedeutung als Nahrungsgrundlage demersaler Fische. Berichte zur Polar- und Meeresforschung.
Alfred-Wegener-Institut für Polar- und Meersforschung, Bremerhaven

Hop H, Pearson TH, Nøst Hegseth E, Kovacs KM, Wiencke C, Kwasniewski S, Eiane K, Mehlum F, Gulliksen B, WlodarskaKowalczuk M, Lydersen C, Weslawski JM, Cochrane S, Gabrielsen GW, Leaky RJG, Lønne OJ, Zajączkowski M, Falk-Petersen S, Kendall M, Wängberg S-A, Bischof $\mathrm{K}$, Voronkov AY, Kovaltchouk NA, Wiktor J, Poltermann M, di Prisco G, Papucci C, Gerland S (2002) The marine ecosystem of Kongsfjorden, Svalbard. Polar Res 21:167-208

Ito H, Kudoh S (1997) Characteristics of water in Kongsfjorden, Svalbard. Proc NIPR Symp Polar Meterol Glaciol 11:211-232

Kaczmarek H, Wlodarska-Kowalczuk M, Legeżyńska J, Zajączkowski M (2005) Shallow sublittoral macrozoobenthos in Kongsfjord, West Spitsbergen, Svalbard. Pol Polar Res 26: $137-155$

Kedra M, Wlodarska-Kowalczuk M, Weslawski JM (2010) Decadal change in macrobenthic soft-bottom community structure in a high Arctic fjord (Kongsfjorden, Svalbard). Polar Biol 33:1-11

Konar B (2007) Recolonization of a high latitude hard-bottom nearshore community. Polar Biol 30:663-667

Konar B (2013) Lack of recovery from disturbance in high-arctic boulder communities. Polar Biol 36:1205-1214

Kuklinski P, Berge J, McFadden L, Dmoch K, Zajczkowski M, Nygard H, Piwosz K, Tatarek A (2013) Seasonality of occurrence and recruitment of Arctic marine benthic invertebrate larvae in relation to environmental variables. Polar Biol 36:549-560

Lackschewitz D, Reise K (1998) Macrofauna on flood delta shoals in the Wadden Sea with an underground association between the lugworm Arenicola marina and the amphipod Urothoe poseidonis. Helgol Meeresunters 52:147-158

Laudien J, Herrmann M, Arntz W (2007) Soft bottom species richness and diversity as a function of depth and iceberg scour in Arctic glacial Kongsfjorden (Svalbard). Polar Biol 30:1035-1046

Legezynska J, Weslawski JM, Presler P (2000) Benthic scavengers collected by baited traps in the high Arctic. Polar Biol 23: 539-544

Markowska M, Janecki T, Kidawa A (2008) Field observations of the spider crab, Hyas araneus (L., 1758): feeding behaviour in an Arctic fjord. Crustaceana 81:1211-1217

Maximovich NV, Guerassimova AV (2003) Life history characteristics of the clam Mya arenaria in the White Sea. Helgol Mar Res 57:91-99

Meysman FJ, Middelburg JJ, Heip CH (2006) Bioturbation: a fresh look at Darwin's last idea. Trends Ecol Evol 21:688-695

Michaelis H, Wolff WJ (2001) Soft-bottom fauna of a tropical (Banc d'Arguin, Mauritania) and a temperate (Juist area, German North Sea coast) intertidal area. In: Reise K (ed) Ecological comparisons of sedimentary shores. Ecological studies 151. Springer, Berlin, pp 255-274

Olafsson EBC, Peterson CW, Ambrose WG (1994) Does recruitment limitation structure populations and communities of macroinvertebrates in marine sediments: the relative importance of pre- and post-settlement processes. Oceanogr Mar Biol Ann Rev 32:65-109

Paine RT (1980) Food webs: linkage, interaction strength and community infrastructure. J Anim Ecol 49:667-685

Passarelli C, Olivier F, Paterson DM, Meziane T, Hubas C (2014) Organisms as cooperative ecosystem engineers in intertidal flats. J Sea Res 92:92-101

Pickering T, Quijon PA (2011) Potential effects of a non-indigenous predator in its expanded range: assessing green crab, Carcinus maenas, prey preference in a productive coastal area of Atlantic Canada. Mar Biol 158:2065-2078 
Pillay D, Branch GM (2011) Bioengineering effects of burrowing thalassinidean shrimps on marine soft-bottom ecosystems. Oceanogr Mar Biol Ann Rev 49:137-192

Quijon PA, Snelgrove PVR (2005) Differential regulatory roles of crustacean predators in a sub-arctic, soft-sediment system. Mar Ecol Prog Ser 285:137-149

Quinn GP, Keough MJ (2002) Experimental design and data Analysis for biologists. University Press, Cambridge

Rabaut M, Guilini K, Van Hoey G, Vincx M, Degraer S (2007) A bioengineered soft-bottom environment: the impact of Lanice conchilega on the benthic species-specific densities and community structure. Estuar Coast Shelf Sci 75:525-536

Reise K (1985) Tidal flat ecology. Springer, Berlin

Reise K (2002) Sediment mediated species interactions in coastal waters. J Sea Res 48:127-141

Riisgard HU, Banta GT (1998) Irrigation and deposit feeding by the lugworm Arenicola marina, characteristics and secondary effects on the environment. A review of current knowledge. Vie Milieu 48:243-257

Strasser M (2002) Reduced epibenthic predation on intertidal bivalves after a severe winter in the European Wadden Sea. Mar Ecol Prog Ser 241:113-123

Strasser M, Dekker R, Essink K, Günther CP, Jaklin S, Kröncke I, Madsen PB, Michaelis H, Vedel G (2003) How predictable is high bivalve recruitment in the Wadden Sea after a severe winter? J Sea Res 49:47-57

Svendsen H, Beszczynska-Møller A, Hagen JO, Lefauconnier B, Tverberg V, Gerland S, Ørbæk JB, Bischof K, Papucci C, Zajączkowski M, Azzolini R, Bruland O, Wiencke C, Winther J-G, Dallmann W (2002) The physical environment of Kongsfjorden-Krossfjorden, an Arctic fjord system in Svalbard. Polar Res 21:133-166

Thompson JC (2002) The influence of hunger and olfactory cues on the feeding behavior of the waved whelk, Buccinum undatum, on the blue mussel, Mytilus edulis. Veliger 45:55-57

Varfolomeeva M, Naumov A (2013) Long-term temporal and spatial variation of macrobenthos in the intertidal soft-bottom flats of two small bights (Chupa Inlet, Kandalaksha Bay, White Sea). Hydrobiologia 706:175-189

Veit-Köhler G, Laudien J, Knott J, Velez J, Sahade R (2008) Meiobenthic colonization of soft sediments in arctic glacial Kongsfjorden (Svalbard). J Exp Mar Biol Ecol 363:58-65

Volkenborn N, Reise K (2006) Lugworm exclusion experiment: responses by deposit feeding worms to biogenic habitat transformations. J Exp Mar Biol Ecol 330:169-179

Volkenborn N, Reise K (2007) Effects of Arenicola marina on polychaete functional diversity revealed by large-scale experimental lugworm exclusion. J Sea Res 57:17-88
Volkenborn N, Hedtkamp SIC, van Beusekom JEE, Reise K (2007) Effects of bioturbation and bioirrigation by lugworms (Arenicola marina) on physical and chemical sediment properties and implications for intertidal succession. Estuar Coast Shelf Sci 74:331-343

Volkenborn N, Robertson DM, Reise K (2009) Sediment destabilizing and stabilizing bio-engineers on tidal flats: cascading effects of experimental exclusion. Helgol Mar Res 63:27-35

Voronkov A, Hop H, Gulliksen B (2013) Diversity of hard-bottom fauna relative to environmental gradients in Kongsfjorden, Svalbard. Polar Res 32: 11208. http://dx.doi.org/10.3402/polar. v32i 0.11208

Wendelboe K, Egelund JT, Flindt MR, Valdemarsen T (2013) Impact of lugworms (Arenicola marina) on mobilization and transport of fine particles and organic matter in marine sediments. J Sea Res 76:31-38

Weslawski JM, Kendall MA, Wlodarska-Kowalczuk M, Iken K, Kedra M, Legezynska J, Sejr MK (2011) Climate change effects on Arctic fjord and coastal macrobenthic diversity-observations and predictions. Mar Biodiv 41:71-85

Wilson WH (1991) Competition and predation in soft-sediment communities. Annu Rev Ecol Syst 21:221-241

Włodarska-Kowalczuk M (2007) Molluscs in Kongsfjorden (Spitsbergen, Svalbard): a species list and patterns of distribution and diversity. Polar Res 26:48-63

Wlodarska-Kowalczuk M, Pearson TH (2004) Soft-bottom macrobenthic faunal associations and factors affecting species distributions in an Arctic glacial fjord (Kongsfjord, Spitsbergen). Polar Biol 27:155-167

Wlodarska-Kowalczuk M, Pearson TH, Kendall MA (2005) Benthic response to chronic natural physical disturbance by glacial sedimentation in an Arctic fjord. Mar Ecol Prog Ser 303:31-41

Woll AK, van der Meeren GI, Fossen I (2006) Spatial variation in abundance and catch composition of Cancer pagurus in Norwegian waters: biological reasoning and implications for assessment. ICES J Mar Sci 63:421-433

Woodin SA (1986) Settlement of infauna: larval choice? B Mar Sci 39:401-407

Woodin SA (1999) Shallow water benthic ecology: a North American perspective of sedimentary habitats. Aust J Ecol 24:291-301

Woodin SA, Lindsay SM, Wethey DS (1995) Process-specific recruitment cues in marine sedimentary systems. Biol Bull 189:49-58

Yakovis EL, Artemieva AV, Fokin MV, Varfolomeeva MA, Shunatova NN (2013) Synchronous annual recruitment variation in barnacles and ascidians in the White Sea shallow subtidal 1999-2010. Hydrobiologia 706:69-79 